\title{
SUSTAINABLE BUILDING DESIGN
}

\author{
Nengmou WANG, Hojjat ADELI \\ Department of Civil Engineering, The Ohio State University, 470 Hitchcock Hall, 2070 Neil Avenue, \\ 43210 Columbus Ohio, USA
}

Received 18 Nov 2013; accepted 25 Nov 2013

\begin{abstract}
Sustainable building design has become a wide and multidisciplinary research endeavor including mechanical, electrical, electronic, communication, acoustic, architectural, and structural engineering. It involves the participation of owners, contractors, suppliers and building users. There has been a lot of talk about sustainable buildings in the past few years. Most of the published research is concerned with saving energy and water and making the buildings more environmentally friendly by, say, reducing the carbon emissions. In this article, sustainable building design is reviewed from the viewpoint of structural engineering. Different strategies presented in the literature are summarized. Finally, the authors argue that the next big leap in sustainable building design should come from the integration of the smart structure technology including the use of hybrid and semi-active vibration controllers that can result in substantially lighter and more efficient structures.
\end{abstract}

Keywords: sustainable building design, material, system, optimization.

Reference to this paper should be made as follows: Wang, N.; Adeli, H. 2013. Sustainable building design, Journal of Civil Engineering and Management 20(1): 1-10. http://dx.doi.org/10.3846/13923730.2013.871330

\section{Introduction}

Twelve years ago, the senior author wrote a visionary viewpoint on "Sustainable Infrastructure Systems and Environmentally-Conscious Design - A View for the Next Decade" (Adeli 2002). He envisioned "successful creation of sustainable infrastructure systems and environmentally-conscious designs requires a holistic, integrated, and multidisciplinary approach" and described technologies that would help create such systems including intelligent system computing, sensor, and life-cycle cost optimization technologies. Subsequently, he presented a vision for a modern Civil and Environmental Engineering program in the $21^{\text {st }}$ century with a theme of Engineering for Sustainability (Adeli 2009). This paper presents a state-of-the-art review of sustainable building design towards realization of Adeli's vision presented 12 years ago.

Sustainable building design is also known as green design or high performance buildings. Blutstein and Rodger (2001) note "A sustainable building requires more than identifying solutions to specific problems, but changes to attitudes, paradigms, processes and systems to deliver the project". Webster (2004) estimates green gas emissions from buildings in the U.S. to be equal to 22 million new cars running $19,000 \mathrm{~km}$ every year. It is estimated that over $70 \%$ of the city's greenhouse gases are emitted from buildings (ARUP 2013), and buildings are responsible for $70 \%$ of the energy use in the U.S. (DOE 2007). Just like hybrid and electric cars are chang- ing the face of the auto industry (Lim et al. 2012; Sedano et al. 2013) the concept of green or sustainable building design is also transforming the construction industry albeit much more slowly.

A report from U.S. Green Building Council (USGBC 2013) notes $24-50 \%$ of energy use, $30 \%$ of $\mathrm{CO}_{2}$ emissions, $40 \%$ of water use, and $70 \%$ of solid water can be reduced for sustainable buildings. Sustainable building design initiatives strive to transform structural developments to more environmentally conscious building design and ultimately improve the quality of life. An estimate made by USGBC a couple of years ago indicated by 2010 approximately $10 \%$ of construction in the U.S. ( $\$ 23$ billion) would involve green design concepts (Turner, Frankel 2008).

According to the USGBC Leadership in Energy and Environmental Design (LEED) Rating System (USGBC 2013), research topics of green building fall into the following six categories: Sustainable Sites, Water Efficiency, Energy \& Atmosphere, Materials \& Resources, Indoor Environmental Quality, and Innovation \& Design Process. The LEED Rating System is used mostly in North America, Brazil and India, while at least five other rating systems are currently used in other countries as summarized in Table 1.

The type of the structural system is one of the most important factors in sustainable design because sustainable design and construction strategies are established based on the form of the structural system. The land use, material use, energy consumption (Pinto et al. 2013; 
Table 1. Sustainable rating systems around the world

\begin{tabular}{l|l|l}
\hline \multicolumn{1}{c|}{ Countries } & \multicolumn{1}{|c}{ Association } & Rating System \\
\hline $\begin{array}{l}\text { Australia, } \\
\text { New Zealand }\end{array}$ & $\begin{array}{l}\text { Green Building Council of } \\
\text { Australia }\end{array}$ & Green Star \\
\hline France & Association HQE & HEQ \\
\hline Germany & $\begin{array}{l}\text { German Sustainable Building } \\
\text { Council }\end{array}$ & GeSBC \\
\hline Japan & $\begin{array}{l}\text { Japan Sustainable Building } \\
\text { Consortium }\end{array}$ & CASBEE \\
\hline UK & $\begin{array}{l}\text { Building Research Establish- } \\
\text { ment }\end{array}$ & BREEAM \\
\hline $\begin{array}{l}\text { U.S., Canada, } \\
\text { Brazil, India }\end{array}$ & U.S. Green Building Council & LEED \\
\hline
\end{tabular}

Abbreviations: GeSBC: The German Sustainable Building Certification; HEQ: High Environmental Quality; CASBEE: Comprehensive Assessment System for Building Environmental Efficiency; BREEAM: Building Research Establishment Environmental Assessment Method; LEED: Leadership in Energy and Environmental Design

Lee et al. 2013), greenhouse gas emissions, maintenance, risk management, life cycle costs (Hegazy et al. 2012), and even recycling depend to a great extent on the selection of the structural system and the form. Many structural engineers tend to underestimate their role in reducing the economic and environmental cost of sustainable building design.

Anderson and Silman (2009) present structural engineering design strategies for reducing greenhouse gases including material selection, reusing the structure, maximizing material efficiency, thermal mass effects, and future adaptability. Thermal mass is an attribute that represents the best combination of its density, thermal conductivity and specific heat capacity for absorbing, storing and slowly releasing heat. Materials with thermal mass effect readily absorb or release excess heat without getting hot significantly. The authors conclude that thermal mass effects provide the greatest potential in reduction of $\mathrm{CO}_{2}$ when operational energy is included, while material selections offer the greatest potential in reduction of $\mathrm{CO}_{2}$ when operational energy is excluded.

Similar to the division of sustainable construction (Maydl 2004), sustainable design can also be divided into three principal categories: ecological, economic, and social sustainability. In terms of sustainable design strategies, structural sustainability concerns can be divided into three categories: structural materials, structural systems, and design optimization.

Ali and Armstrong (2008) present four strategies for sustainable tall buildings: passive solar gain, active solar gain, active wind gain, and façade technology. For passive solar gain, the best thermal value can be achieved through structural orientation towards the seasonal paths of the sun. Active solar gain includes solar collectors and photovoltaic (PV) panels. Application of PV cells in tall buildings has been increasing significantly in recent years (IEA 2003). The energy gain and loss in a tall building depend heavily on the materials and technology employed in the façade design (Brzezicki 2012). In that context the roof is nearly inconsequential because a very large percentage of the external surface of a tall building is covered by façade. Façade design not only determines the aesthetic appearance of buildings, but also controls the internal conditions of the structure in the case of buildings with double or triple skins.

\section{Structural materials}

\subsection{Timber and alternative lumber}

Traditional structural materials such as timber, masonry, concrete, steel, glass, and aluminum provide different environmental and energy performance. Wood can be used as a recycled and harmless product in low rise buildings. In recent years, alternative lumber made of recycled materials such as composite lumber or plastic lumber (a recyclable material made of virgin or waste plastic) has found increasing applications especially for outdoor decks (Austin Energy 2013). Compared with traditional woods such as yellow pine, untreated cedar, and redwood used in outdoor decks, alternative lumber has better aesthetics, slip-resistance, and durability. Alternative lumber can cost less in the long run because it requires little maintenance during its life time.

Ibrahim (2008) presents design of a light prestressed segmented trussed arch made of sustainable small diameter round woods or log members with their natural growth rings. The truss members are joined with connectors in the form of simple thin-walled steel welded pipe clusters, hot-dip galvanized for durability. The author notes "for larger scale standardized structures, cast aluminum alloys or similar materials may result in even more savings, less maintenance, longer life-span and better aesthetics". Two such bridges with a span of $19.5 \mathrm{~m}$ have been built. Miller (2008) describes the 27.5m-span Rattlesnake Creek Trail Bridge in Missoula, Montana, a truss-suspension bridge built using mostly recycled materials. The truss members are small diameter round woods "salvaged from bug-killed lodgepole pine". This bridge is further proven to be in harmony with its natural environment.

\subsection{Masonry and concrete}

Masonry provides certain advantages in sustainable construction. First, it can keep warm or cool very long because of its thermal insulation property. Second, masonry can provide a natural indoor environment without the need for painting. Also, it is easy to find masonry materials in most regions of the world.

Concrete consists mainly of aggregates and cement paste. When the paste gets older it releases $\mathrm{CO}_{2}$ gas as a result of chemical reaction. Nearly one pound of $\mathrm{CO}_{2}$ per pound of cement is emitted during its life time (Kang, Kren 2007). In order to reduce the gas emission, Portland Cement Association (PCA) recommends adding fly ash and slag to the traditional cement (PCA 2013).

In the context of concrete materials Meyer (2004) provides five possible strategies for sustainable design: 1) increased use of supplementary materials such as fly ash and ground granulated blast furnace slag; 2) increased use of the recycled materials for the aggregate to mini- 
mize the use of fresh aggregates; 3 ) improved durability by increasing the service life of the structure (for example, if the service life of a structure is increased by $50 \%$ the materials needed to replace the structure would be reduced by one third); 4) improved mechanical properties (higher strength means less materials would be needed); and 5) reuse of wash water and other waste products such as construction debris, consumed glass, dredged materials, recycled carpets, tires, etc.

\subsection{Steel}

In terms of recyclability, steel receives high marks as a construction material. According to a report by Steel Recycling Institute (2013), the overall steel recycling rate for the year 2008 was $83.3 \%$. The recycling rates of steel used in structures was about $97.5 \%$ during 2004-2008, compared with no more than $70 \%$ for concrete in 2008 . Another advantage of steel is its ease of disassembly. In that respect, bolted connections are superior to welded connections.

\subsection{Aluminum}

Radlbeck et al. (2006) point out superior properties of aluminum in sustainable design such as low weight and maintenance, and high corrosion-resistance and recycling. The authors perform a Life-Cycle-Cost-Analysis (LCCA, for cost evaluation) and Life Cycle Assessment (LCA, for environmental evaluation) of two aluminum buildings, and report that compared with a similar steel structure the two aluminum structures have a higher ratio of load bearing capacity to dead load, a better corrosion resistance, and lower maintenance requirement. The authors assert that aluminum structures, if designed and executed properly, may have a better ecological and economical performance in the long run compared with steel.

\subsection{High-strength and light-weight composite materials}

Ali and Armstrong (2008) advocate the use of highstrength and light-weight composite materials such as carbon fiber reinforced composites (Finckh, Zilch 2012) proposed for a 40 story multi-use Carbon Tower designed by Peter Testa. The use of such materials will result in much lighter structures.

Galbraith (2008) discusses several sustainable design strategies based on his experience of building in the harsh and hot environment of the Persian Gulf area that involve both materials and structural forms: 1) use regular frames to result in the repeated use of the forms; 2) use pulverized fly ash to replace cement; 3) reduce steel reinforcing by $10-15 \%$ through the use of appropriate detailing; 4) use steel in place of wood for shoring of the formwork because of lack of timber in that region; $5)$ use post-tensioning to reduce concrete and reinforcing quantity; 6) use flat slab to reduce the formwork. The author further recommends reducing the use of materials with a high energy demand in their production such as concrete masonry block walls, and use of cellular steel beams in steel buildings because they are substantially lighter than corresponding wide flange beams.

\section{Structural systems}

A decade ago Department of Energy's Office of Energy Efficiency and Renewable Energy (DOE 2000) introduced an advanced wall framing system with the goal of reducing "the amount of lumber used and waste generated in the construction of a wood-framed house". It provides simple strategies such as increasing the stud spacing from 16 in to 24 in, in-line framing ("Align floor, wall, and roof framing members directly above or below one another so that loads are transferred directly downward"), and designing "building length, width, and roof pitch in 2-foot increments to make the best use of common sheet good sizes".

Buschmeyer and Fastabend (2004) point out that a key element to sustainable design is the adaptability of the structural system in order to minimize the cost of future changes. They suggest four principles for sustainable design: 1) plan a minimum height for the structure within architectural and aesthetic limitations so as to reduce the wind loads as well as the use of materials; 2) make foundational slab easily accessible to be strengthened in the future; 3) plan simple slabs to accommodate future design changes; 4) equip bridges with proper ports and anchorages for future pre-stressing.

Al-Sallal (2004) suggests that highrise towers with a rectangular plan configuration and an aspect ratio of 1:2 to 1:3 (with the long sides oriented in the north-south direction) is the best near the equatorial zone in reducing the solar heat gain. Carmody et al. (2007) suggest awnings as a sustainable component in buildings. Based on the data from twelve U.S. cities, the authors point out two benefits of awnings. First, since the sunshine heat passing through windows is reduced the cooling energy and consequently emission of green gas is reduced. Second, peak electricity demand is decreased resulting in additional savings in the energy cost.

Collins et al. (2008) suggest strategies for structural forms that include: 1) optimization of climatic conditions such as solar gain, day lighting, and wind harvesting; 2) creating structures with wind load response; and 3) cocoordinated environmental strategies considering service design, façade design and structural form together, such as natural ventilation.

Wood (2008) offers five design principles in the context of aesthetics of highrise building sustainability: 1) variation with height: variation of both form and skin with height can offer a better visual relationship with surrounding buildings in a city; 2) multiple functions: rather than the regular office, residential, and hotel use, tall buildings are increasingly required to be mixed-used and to incorporate multiple functions. The author suggests radical incorporation of functions such as sports, for example, external solar control skin as rock-climbing wall and tuned mass damper (Kang et al. 2012) as swimming pool, or agriculture, for example, hydroponic greenhouse and facade farms; 3) communal spaces with 
more open and entertainment spaces; 4) envelop opacity without extensive solar gain and glare and with insulation from external temperature variations; 5) vegetation: Vegetation improves both structural and urban scales. An example of this approach is the COR Tower (Fig. 1) designed by "Oppenheim Architect + Design" in 2007. This building which is equipped with wind turbines in its facades strives to achieve a balance between transparency and opacity in its skin.

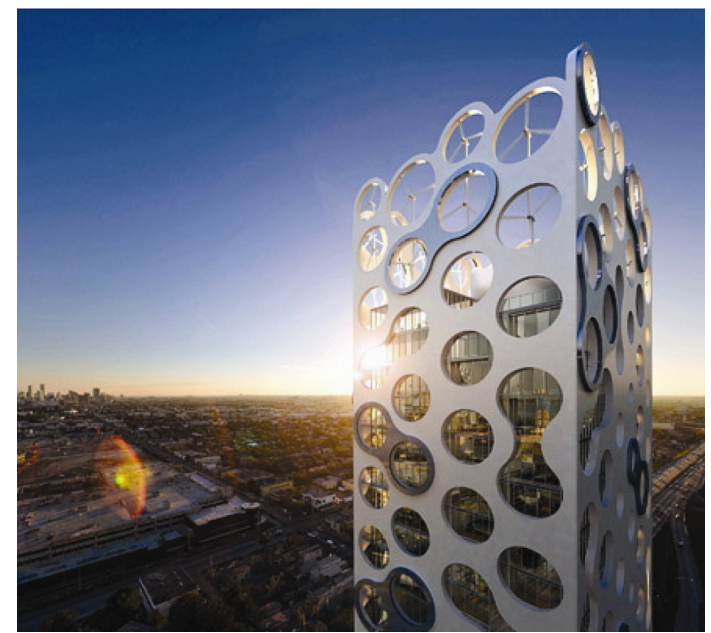

Fig. 1. COR Tower designed for Miami (courtesy of Oppenheim Architect + Design)

Tamboli et al. (2008) discuss the sustainable design of three major tall buildings: Taipei 101, Taiwan; Petronas Towers, Malaysia; and Random House Tower, New York. Fly-ash concrete and recycled steel are used in all three buildings. The 206-m Random House Tower is also the first tall building with a tuned liquid column damper (TLCD) (Kim, Adeli 2005a, b) in the U.S. to reduce the lateral vibrations. The TLCD not only reduces the deflections and accelerations at the top floors and provides better structural stability but the water in the tanks of the TLCD can also be used in fire fighting and as chilled water storage (Ghaemmaghami et al. 2013). The TLCD system uses water in place of additional concrete or steel used in traditional tuned mass damper (TMD) systems (Cho et al. 2012; Amini et al. 2013). This substitution provides three different economic benefits: first, TLCD is less costly than traditional TMD; second, it reduces the structural maintenance requirements; third the effectiveness of the TLCD increases when the building become less stiff as a result of the concrete cracking during a dynamic event (seismic or wind) or wear and tear of non-structural elements over time. In addition, TLCD offers better health environment by reducing structural acceleration and inter-story drifts during moderate dynamic events.

Charnish and McDonnell (2008) introduce the tallest building in Calgary and Western Canada, a 59-story bow-shaped building at nearly 247 meters ( 810 feet) high (Fig. 2). During the design phase, several lateral force resisting systems were considered including reinforced concrete core wall, structural steel shear wall, a hybrid system of core and outriggers, mega-diagonals through the tower interior, a rigid frame perimeter tube of closely spaced columns, and the perimeter trussed tube in a triangular shape diagonal grid, called diagrid, with six-story high diagonals along the curved north and south elevations. The diagrid form was selected partly for architectural expression and aesthetics. It avoids the use of interior concrete shear wall to maximize the open interior space. The placement of the diagrid nodes in a uniform triangular manner every six floors provides for the repetition of the components and connections to minimize the fabrication and erection costs. Compared with a conventional braced core or rigid frame perimeter tube structure, this perimeter diagrid system is claimed to reduce about $20 \%$ of the structural steel weight by using structural efficiencies of its curved form.

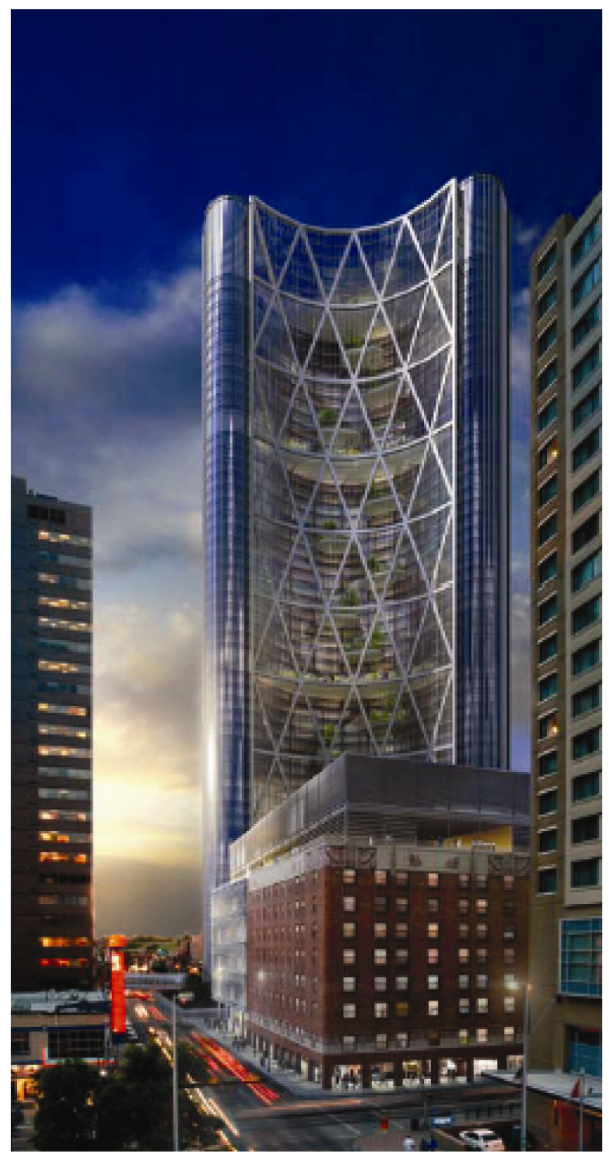

Fig. 2. The "Bow" Diagrid Tower (courtesy of Foster + Partners)

In high seismic areas, for tall buildings taller than 240 feet moment frames and dual systems are the two primary systems recommended by codes such as the Uniform Building Codes (UBC). In tall buildings, moment frames usually placed at the perimeter require large column and beam sizes which can obstruct the view and create limitations for balconies. Such frames also lose their efficiency for providing lateral stiffness for buildings taller than 20 stories. Dual systems with a stiff concrete or steel core solve the stiffness problem but perimeter obstruction issue still remains to some extent. Lahey et al. (2008) present a 
dual structural system for the twin 55-story and 45-story One Rincon Hill in San Francisco consisting of a stiff central concrete core with 8-inch-thick post-tensioned concrete flat slabs that extend to the perimeter of the building. To add stiffness to the relatively slender central core, outriggers were added in the form of buckling-restrained $\mathrm{K}$ bracings. The result is a building geometry which can maximize views, maintain unit-planning flexibility, and minimize view encumbrances. A TLCD system is used to minimize occupant comfort during the winds. The authors assert these tall buildings have brought "high-quality residential design to urban centers in the form of sustainable, inventive, and elegant buildings".

Baldridge (2008) discusses tall building sustainability in the context of the Hawaiian Islands. Height restrictions are imposed for tall buildings in many municipalities such as Washington, DC, and Honolulu where building heights are limited in most areas to $350-400 \mathrm{ft}$. Under such conditions, a maximum number of floors can be achieved by either decreasing floor-to-floor height or minimizing the slab thickness. Both will add to the building sustainability because they will increase tall building efficiency and economic viability. Many high rise buildings in Honolulu have been built with a floor-to-floor height of 8 ' 6 " or less. To minimize the slab thickness they are post-tensioned with many projects having a slab thickness of only $5 \mathrm{in}$. The author notes this thickness helps squeeze 47 floors in a 400 -foot high building. In addition, Baldridge (2008) provides several strategies for increasing structural system efficiency of tall buildings and consequently sustainability: 1) Coupled shear walls A higher stiffness and strength can be achieved by connecting two or more shear walls with beams than the sum of stiffnesses and strengths of the walls used independently (in seismic regions, however, special precautions have to be taken in the detailing of coupled shear walls because their behavior becomes more complicated and therefore more damage prone as noted in the 14-story McKinley apartment building 1964 Alaska earthquake); 2) Outrigger systems - Increase the moment arm by distributing the overturning forces with full floor links; 3) Punched shear wall - In residential highrise buildings exterior concrete walls can be used with opening for windows to develop frame or tube action depending on the width of windows; 4) Shear wall-frame interaction Frame action can reduce some demands on the shear walls; 5) to minimize the torsional effects and consequently maximize the structural efficiency the center of rigidity of the shear walls should be as close to the building's center of mass for seismic force and the center of wind exposure for wind forces; and 6) An optimal regular-shaped building should have the same center for mass and wind exposure.

To achieve design sustainability designers are coming up with innovative three-dimensional (3D) structural systems. An example is the 56-story, $232 \mathrm{~m}$ tall Jinao Tower in Nanjing (Fig. 3), China, where the structural system consists of a reinforced concrete tube-in-tube structure wrapped with a perimeter braced steel frame outside of the tube-in-tube system and between a doubleskinned façade within a faceted external form (Sarkisian et al. 2010). The authors claim "a $40 \%$ design reduction in concrete and rebar in the concrete lateral load resisting system and a $20 \%$ design reduction in concrete and rebar for the overall building structure". The double skinned façade with a glass and aluminum outer skin provides solar shading and improved heating and cooling insulation. Horizontally formed aluminum openings at every $16 \mathrm{~m}$ in height were tailored to optimize air movement horizontally along the inner wall based on computational fluid dynamic analysis. The authors claim the buffered air temperature within the skin together with the horizontal slot openings reduce up to $20 \%$ of the energy requirement for the primary mechanical system.
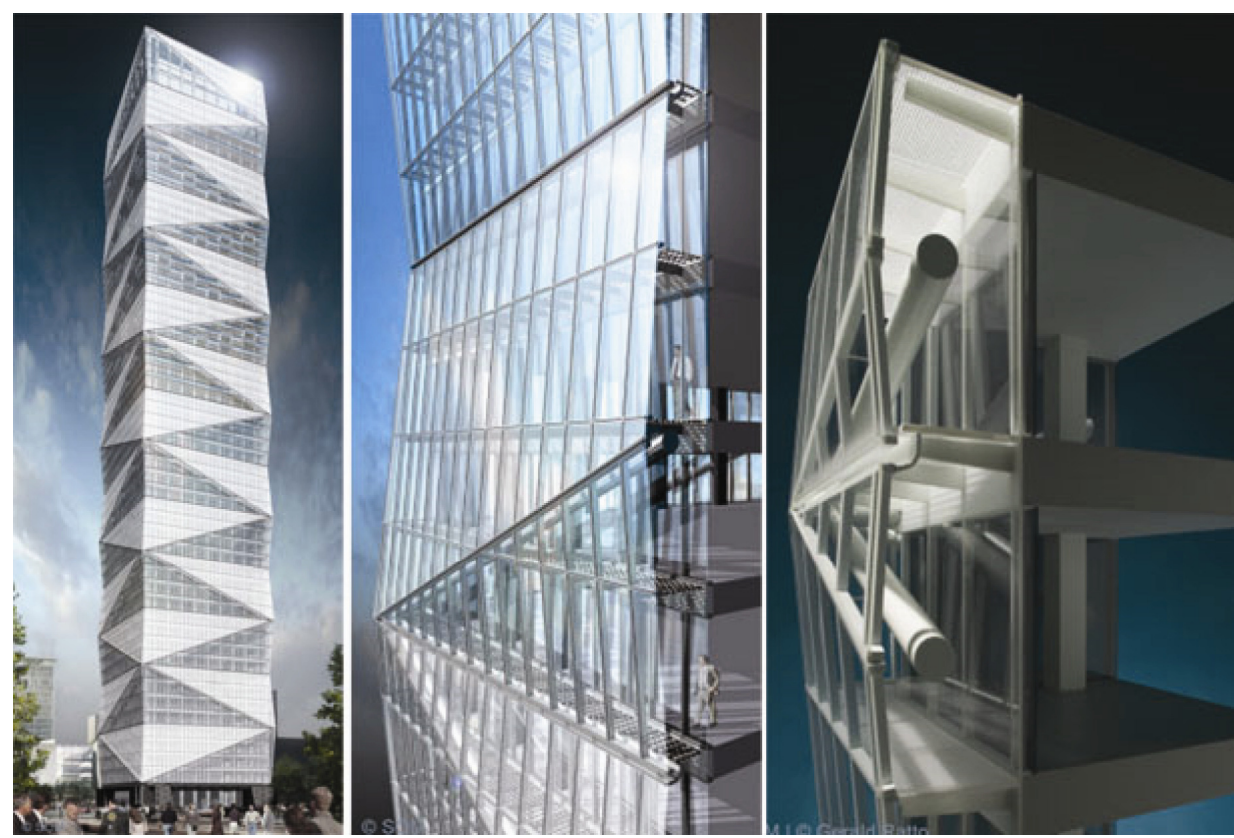

Fig. 3. Jinao Tower in Nanjing, China (courtesy of Skidmore, Owings \& Merrill LLP) 
Sustainable design does not necessary mean a design with a higher cost. For David Brower Center in Berkeley, an office complex for a non-profit organization, located close to the San Andreas seismic fault, designers used post-tensioned concrete walls and frames with blast furnace slag substituted for most of the cement used in the concrete with apparently no additional costs to owners (High-Performance Green Buildings 2013).

\section{Energy and water}

Creative use of natural lighting and ventilation with appropriate sky courts and vertical landscapes can reduce the energy demand considerably.

\subsection{Combined Heat and Power (CHP) system}

In densely-populated urban areas, an energy-efficient technology is a Combined Heat and Power (CHP) system which refers to the simultaneous production of power, heat, and chilled water for air conditioning. Ali and Armstrong (2008) suggest CHP results in considerable cost savings and reduction of $\mathrm{CO} 2$ emissions.

\subsection{Solar energy}

Harvesting of solar energy is more efficient at the top of a tall building especially for areas and cities with directbeam radiation such as Las Vegas. Schlaich et al. (2004) advocate the use of solar updraft towers over the traditional electricity generation using fossil fuels with their negative impact on the environment. They propose "utilizing a combination of a solar air collector and a central updraft tube to generate a convective flow which drives pressure staged turbines to generate electricity".

\subsection{Wind energy}

Wind energy as a renewable energy source has potential in tall buildings. Tall buildings can be designed to funnel wind into an area containing wind turbines without any effect on the structural performance such as acceleration, interstory displacement, or lateral drift. More sustainable structures can be achieved through a combination of design for structural performance and use of wind energy.

Leung and Weismantle (2008) indicate that wind movement can be achieved between interior and exterior environmental conditions. This movement is able to be captured for passive cooling and ventilation.

\subsection{Geothermal energy}

Another environmentally friendly way of producing energy for buildings is the geothermal energy with heat pump technology. It has been used for heating many small buildings over the past decades. Their application in tall buildings is a recent development.

\subsection{Fuel cells}

Fuel cells consisting of hydrogen and oxygen are being used in sustainable design, for example, in the 48-story concrete Conde Nast Building in New York City (Ali, Armstrong 2008). Their prices are currently too high but are expected to decrease substantially in the coming years.

\subsection{Smart houses}

The concept of smart house is based on the use of technologies that maximizes efficient use of energy consumption from automated systems to the remote control of the house conditions via Internet (Ko et al. 2012).

\section{Life cycle cost assessment}

Although a building can be designed to achieve sustainability, it is necessary to assess its performance quantitatively. This has to be done in the context of optimization of the environmental impact and/or life cycle cost of buildings (Sarma, Adeli 2002). A few frameworks have been developed recently to evaluate the energy performance and life cycle cost of buildings.

For life cycle assessment (LCA) and evaluation of the environmental impact of building systems during their life time Webster (2004) divides the life cycle impact into four categories: (a) initial effects including the construction and manufacturing of raw materials; (b) energy use during the life cycle of the building system; (c) renovation effects; and (d) end-of-life effects, that is, the environmental effects after the life cycle. Several important factors must be considered in LCA including energy consumption, resource use, and green gas and pollution production. The initial impacts are mainly influenced by the building and construction type. Renovations, maintenance, and refurbishment depend more on the structural materials and less on the structural form. Disposal of structural materials have an end-of-life impact on the life cycle assessment.

Ochsendorf (2004) presents successful and unsuccessful examples of sustainable design in the history in the context of bridge design. As a poor example of sustainability, the maintenance and rehabilitation of the old Williamsburg Bridge in New York City cost $\$ 1$ billion during the 15-year period 1990-2004, which is more than its replacement cost of $\$ 700$ million in 1988 . In contrast, a Roman arch bridge made of mainly high quality masonry 2000 years ago may have a relatively high initial cost but has a very low maintenance cost. From the perspective of economy and environment a Roman arch bridge receives high score as a sustainable design. At the opposite end is the Inca suspension bridge made of plant materials built in Peru originally 600 years ago. It has a very high maintenance cost as it has to be replaced every year. This comparison indicates the importance of considering both environmental impact and economic consideration in structural design.

Rajagopalan et al. (2009) conducted a comparative life cycle assessment of the wall sections comprised of insulating concrete forms (ICF, a kind of insulating concrete forms consisting of expanded polystyrene and concrete with polyethylene ties) and traditional wood-framed for the life cycle phases of raw materials, manufacturing, construction, use and end of life. Elementary comparisons between ICF and wood frame in the manufacturing phase for above grade construction are presented. An energy 
modeling tool, eQuest, is utilized and the development discussion of the LCA residential model is explained to study the use phase.

Shi and Xie (2009) propose an environmental problems and resources consumption evaluation model for green construction by combining the fuzzy set theory (Yan, Ma 2012; Liu, Er 2012; Fougères, Ostrosi 2013; Kodogiannis et al. 2013) and a quality function deployment method. They use a value engineering approach to solving the problem of the green construction alternatives optimization. McCuskey et al. (2007) proposed a metric for structural sustainability evaluation by using the theory of possibility. Both partial credit and several types of uncertainties in the evaluation process are considered. A case study is presented to explain how the proposed metric incorporates definitions across existing sustainability measures. Tang and Kim (2004) present a simulation environment to help architects and engineers deal with sustainability design issues including energy consumption, air quality, lighting, natural ventilation, comfort, fire and safety concurrently. Fazlic (2008) discusses design strategies for environmentally sustainable residential skyscrapers.

\section{Conclusions}

Table 2 summarizes the LEED rating points. Materials and Resources hold only 13 possible points out of the 69 points in the rating system. Further, Innovation \& Design Process occupies even less, a mere 5 points out of the total 69 points. Authors concur with the current consensus of the engineers that more weight be given not only for materials but also for innovation and design of structural systems.

Table 2. The LEED rating points

\begin{tabular}{l|c}
\hline \multicolumn{1}{c|}{ Categories } & Possible Points (Total 69) \\
\hline Sustainable Sites & 14 \\
\hline Water Efficiency & 5 \\
\hline Energy \& Atmosphere & 17 \\
\hline Materials \& Resources & 13 \\
\hline Indoor Environmental Quality & 15 \\
\hline Innovation \& Design Process & 5 \\
\hline
\end{tabular}

Research topics in sustainable building design consist of many aspects such as:

1) sustainable sites: land use, ecosystem, vegetation on roof, etc.;

2) water and energy efficiency: including reduction of water use, fossil fuel consumption, and carbon emissions, increasing use of renewable energy from solar, wind, and wave;

3) community connection: including preserving local cultural and natural characters of the region, communal spaces with more open and entertainment spaces;

4) service design: more creative leisure-related functions;
5) comprehensive design: considering the entire building and structural systems throughout their life cycle.

From the perspective of architectural, building, and structural engineering, sustainable design falls into three basic categories: structural materials, structural systems, and optimization. Structural sustainability heavily depends on the selection of structural materials, systems, and configurations. For the selection of structural materials, possible strategies include:

1) Increasing the use of supplementary materials such as fly ash and ground granulated blast furnace slag;

2) Improving mechanical properties of structural materials including their durability to increase the service life of the structures;

3) Reuse of wash water and other waste products such as construction debris, glass, dredged materials, recycled carpets, tires, etc.;

4) Reducing the use of materials with a high demand for energy production, such as concrete masonry block walls;

5) Using light-weight composite materials such as carbon fiber reinforced composite materials with increased structural strength-to-mass ratios;

6) Variation with height. The form and skin variance with height can also offer a better visual relationship with surrounding buildings in a city;

7) Environmental response design including multiple façade design, natural ventilation, solar gain, day lighting, and wind harvesting.

For the design of structural systems and forms, possible strategies include:

1) Use of more regular frames and forms for the purpose of reuse;

2) Post tensioning to reduce concrete and reinforcing quantity;

3) In non-seismic regions using flat slabs to reduce formwork use and posted-tensioned slabs to minimize slab thickness and increase floor spaces (in seismic regions such systems have not performed well during major earthquakes);

4) Using cellular steel beams in steel buildings, and bolted connections rather than welded connections for future disassembly and/or reuse;

5) Using more adaptable structural systems such as easily accessible and strengthened foundations, simple slabs to accommodate future design changes, and proper ports and anchorages in bridges for future pre-stressing;

6) Keeping the shear wall center of rigidity close to the building's center of mass for seismic design and the center of wind exposure for wind design. An optimal shaped building should have the same center for mass and wind exposure;

7) Using innovative structural systems such as the diagrid form, outrigger systems with larger moment arms, exterior shear wall punched for windows, and TMD and TLCD systems; 
8) Optimizing the structural systems using advanced optimization tools (Adeli, Park 1998; Adeli, Sarma 2006).

Finally, the authors argue that the next big leap in sustainable building design should come from the integration of sustainable design ideas with smart structure technology including the use of hybrid and semi-active vibration controllers that can result in substantially lighter and more efficient structures (Adeli, Saleh 1999; Adeli, Kim 2009; Adeli, Jiang 2009). This area should be the next frontier of innovations in structural engineering.

\section{References}

Adeli, H. 2002. Sustainable infrastructure systems and environmentally-conscious design - a view for the next decade, Journal of Computing in Civil Engineering ASCE 16(4): 1-4. http://dx.doi.org/10.1061/(ASCE)0887-3801 (2002)16:4(231)

Adeli, H. 2009. Vision for civil and environmental engineering departments in the $21^{\text {st }}$ century, Journal of Professional Issues in Engineering Education and Practice 135(1): 1-3. http://dx.doi.org/10.1061/(ASCE)1052-3928(2009) 135:1(1)

Adeli, H.; Jiang, X. 2009. Intelligent infrastructure - neural networks, wavelets, and chaos theory for intelligent transportation systems and smart structures. Boca Raton, Florida: CRC Press, Taylor \& Francis. 440 p.

Adeli, H.; Kim, H. 2009. Wavelet-based vibration control of smart buildings and bridges. Boca Raton, Florida: CRC Press, Taylor \& Francis. 238 p.

Adeli, H.; Park, H. S. 1998. Neurocomputing for design automation. Boca Raton, Florida: CRC Press. 240 p.

Adeli, H.; Saleh, A. 1999. Control, optimization, and smart structures - high-performance bridges and buildings of the future. New York: John Wiley and Sons. 288 p.

Adeli, H.; Sarma, K. 2006. Cost optimization of structures fuzzy logic, genetic algorithms, and parallel computing. West Sussex: John Wiley and Son. 222 p. http://dx.doi.org/10.1002/0470867353

Ali, M.; Armstrong, P. 2008. Overview of sustainable design factors in high-rise buildings, in Proc. of the CTBUH $8^{\text {th }}$ World Congress, 3-5 March, 2008, Dubai, 282-291.

Al-Sallal, K. 2004. Tower buildings in Dubai - are they sustainable?, in Proc. of CTBUH Conference, 10-13 October, 2004, Seoul, Korea, 639-647.

Amini, F.; Khanmohamadi Hazaveh, N.; Abdolahi Rad, A. 2013. Wavelet PSO-based LQR algorithm for optimal structural control using active tuned mass dampers, Computer-Aided Civil and Infrastructure Engineering 28(7): 542-557. http://dx.doi.org/10.1111/mice.12017

Anderson, J. E.; Silman, R. 2009. A life cycle inventory of structural engineering design strategies for greenhouse gas reduction, Structural Engineering International 19(3): 283-288. http://dx.doi.org/10.2749/101686609788957946

ARUP. 2013. Sustainable buildings design [online], [cited 10 October 2013]. Available from Internet: http://www.arup. com/Services/Sustainable_Buildings_Design.aspx

Austin Energy. 2013. Energy efficient programs. Green building resources [online], [cited 10 October 2013]. Available from Internet: http://www.austinenergy.com/Energy\% 20Efficiency/Programs/Green\%20Building/Resources/ Fact\%20Sheets/deckLumberAlts.pdf
Baldridge, S. 2008. Tall structural sustainability in an island context: The Hawaii experience, in Proc. of the CTBUH $8^{\text {th }}$ World Congress, 3-5 March, 2008, Dubai, 669-678.

Blutstein, H.; Rodger, A. 2001. The sustainable tall building of the third millennium, in Proc. of the CTBUH $6^{\text {th }}$ World Congress, 26 February-2 March, 2001, Melbourne, Australia, 131-142.

Brzezicki, M. 2012. The influence of reflected solar glare caused by the glass cladding of a building. Application of caustic curve analysis, Computer-Aided Civil and Infrastructure Engineering 27(5): 347-357.

http://dx.doi.org/10.1111/j.1467-8667.2011.00751.x

Buschmeyer, W.; Fastabend, M. 2004. Methods for raising sustainable design of concrete structures, Structural Engineering International 14(3): 195-197. http://dx.doi.org/10.2749/101686604777963766

Carmody, J.; Haglund, K.; Huang, Y. J. 2007. Awnings in residential buildings: the impact on energy use and peak demand in twelve U.S. cities. Summary Report. Version 2.1. The University of Minnesota, Twin Cities Campus, College of Design. 5 p.

Charnish, B.; McDonnell, T. 2008. The bow: unique diagrid structural system for a sustainable tall building, in Proc. of the CTBUH $8^{\text {th }}$ World Congress, 3-5 March, 2008, Dubai, 380-384.

Cho, B. H.; Jo, J. S.; Joo, S. J.; Kim, H. 2012. Dynamic parameter identification of secondary mass dampers based on full-scale tests, Computer-Aided Civil and Infrastructure Engineering 27(3): 218-230. http://dx.doi.org/10.1111/j.1467-8667.2011.00740.x

Collins, A.; Watts, S.; McAlister, M. 2008. The economics of sustainable tall buildings, in Proc. of the CTBUH $8^{\text {th }}$ World Congress, 3-5 March, 2008, Dubai, 175-185.

DOE. 2000. Advanced wall framing - build efficiently, use less material, and save energy! Department of Energy's Office of Energy Efficiency and Renewable Energy [online], [cited 10 October 2013]. Available from Internet: http://www.energystar.gov/ia/home_improvement/home_s olutions/doeframing.pdf

DOE. 2007. Energy consumption by sector, ranked by state. Energy Information Administration, United States Department of Energy [online], [cited 10 October 2013]. Available from Internet: http://www.eia.doe.gov/emeu/ states/sep_sum/plain_html/rank_use.htm

Fazlic, S. 2008. Design strategies for environmentally sustainable residential skyscrapers, in Proc. of the CTBUH $8^{\text {th }}$ World Congress, 3-5 March, 2008, Dubai, 808-818.

Finckh, W.; Zilch, K. 2012. Strengthening and rehabilitation of reinforced concrete slabs with carbon fiber reinforced polymers using a refined bond model, Computer-Aided Civil and Infrastructure Engineering 27(5): 333-346. http://dx.doi.org/10.1111/j.1467-8667.2011.00752.x

Fougères, A. J.; Ostrosi, E. 2013. Fuzzy agent-based approach for consensual design synthesis in product configuration, Integrated Computer-Aided Engineering 20(3): 259-274.

Galbraith, K. 2008. Structural sustainability in the gulf - fact and fiction, in Proc. of the CTBUH $8^{\text {th }}$ World Congress, 3-5 March, 2008, Dubai, 127-131.

Ghaemmaghami, A.; Kianoush, R.; Yuan, X. 2013. Numerical modeling of dynamic behaviour of annular tuned liquid dampers for applications in wind towers, Computer-Aided Civil and Infrastructure Engineering 28(1): 38-51. http://dx.doi.org/10.1111/j.1467-8667.2012.00772.x 
Hegazy, T.; Elhakeem, A.; Ahluwalia, S. S.; Attalla, M. 2012. MOST-FIT: Support techniques for inspection and life cycle optimization in building asset management, Computer-Aided Civil and Infrastructure Engineering 27(2): $130-142$. http://dx.doi.org/10.1111/j.1467-8667.2011.00729.x

High-performance green buildings. 2013. Construction Week Online [online], [cited 10 October 2013]. Available from Internet: http://www.constructionweekonline.in/article5895-high_performance_green_buildings/.

Ibrahim, A. K. 2008. Light prestressed segmented arch (LPSA) bridges: a demonstration of sustainable engineering, Structural Engineering International 18(1): 62-66. http://dx.doi.org/10.2749/101686608783726759

IEA. 2003. Renewables for power generation. International Energy Agency. Organization for Economic Cooperation and Development, France [online], [cited 10 October 2013]. Available from Internet: http://www.iea.org/text base/nppdf/free/2000/renewpower_2003.pdf

Kang, G. S.; Kren, A. 2007. Structural engineering strategies towards sustainable design, in Proc. of the 2006 Structural Engineers Association of Northern California (SEAONC), 13-16 September, 2006, Long Beach, California, 473-490.

Kang, N.; Kim, H.; Choi, S.; Jo, S.; Hwang, J. S.; Yu, E. 2012. Performance evaluation of TMD under typhoon using system identification and inverse wind load estimation, Computer-Aided Civil and Infrastructure Engineering 27(6): 455-473.

http://dx.doi.org/10.1111/j.1467-8667.2011.00755.x

Kim, H.; Adeli, H. 2005a. Hybrid control of irregular steel highrise building structures under seismic excitations, International Journal for Numerical Methods in Engineering 63(12): 1757-1774.

http://dx.doi.org/10.1002/nme.1336

Kim, H.; Adeli, H. 2005b. Wind-induced motion control of 76-story benchmark building using the hybrid dampertuned liquid column damper system, Journal of Structural Engineering 131(12): 1794-1802. http://dx.doi.org/10. 1061/(ASCE)0733-9445(2005)131:12(1794)

Ko, H.; Marreiros, G.; Morais, H.; Vale, Z.; Ramos, C. 2012. Intelligent supervisory control system for home devices using a cyber physical approach, Integrated ComputerAided Engineering 19(1): 67-79.

Kodogiannis, V. S.; Amina, M.; Petrounias, I. 2013. A clustering-based fuzzy-wavelet neural network model for shortterm load forecasting, International Journal of Neural Systems 23(5): 1350024. 19 p.

Lahey, J.; Wolf, M.; Klemencic, R.; Johansson, O. 2008. A tale of two cities: collaborative innovations for sustainable towers, in Proc. of the CTBUH $8^{\text {th }}$ World Congress, 3-5 March, 2008, Dubai, 362-372.

Lee, S. H.; Augenbroe, G. J. K.; Zhao, F. 2013. A design methodology for energy infrastructures at the campus scale, Computer-Aided Civil and Infrastructure Engineering 28(10): 753-768.

Leung, L.; Weismantle, P. 2008. Sky-sourced sustainability how super tall buildings can benefit from height, in Proc. of the CTBUH $8^{\text {th }}$ World Congress, 3-5 March, 2008, Dubai, 328-335.

Lim, Y.; Kim, H. M.; Kang, S.; Kim, T. 2012. Vehicle-to-grid communication system for electric vehicle charging, Integrated Computer-Aided Engineering 19(1): 57-65.
Liu, F.; Er, M. J. 2012. A novel efficient learning algorithm for self-generating fuzzy neural network with applications, International Journal of Neural Systems 22(1): 21-35. http://dx.doi.org/10.1142/S0129065712003067

Maydl, P. 2004. Sustainable engineering: state-of-the-art and prospects, Structural Engineering International 14(3): 176-180. http://dx.doi.org/10.2749/101686604777963928

McCuskey, M. C.; Reda Taha, M. M.; Bogus, S. 2007. A robust sustainability metric using possibility distributions, in Proc. of the 2007 ASCE International Workshop on Computing in Civil Engineering 261(59): 494-501.

Meyer, C. 2004. Concrete materials and sustainable development in the USA, Structural Engineering International 14(3): 203-207. http://dx.doi.org/10.2749/101686604777963757

Miller, B. 2008. Suspension trail bridge using sustainable materials, Montana, Structural Engineering International 18(1): 40-42. http://dx.doi.org/10.2749/101686608783726722

Ochsendorf, J. 2004. Sustainable structural design: lessons from history, Structural Engineering International 14(3): 192194. http://dx.doi.org/10.2749/101686604777963865

Pinto, T.; Praça, I.; Vale, Z.; Morais, H.; Sousa, T. M. 2013. Strategic bidding in electricity markets: an agent-based simulator with game theory for scenario analysis, Integrated Computer-Aided Engineering 20(4): 335-346.

Portland Cement Association (PCA). 2013. Recommendations [online], [cited 10 October 2013]. Available from Internet: http://www.cement.org/

Radlbeck, C.; Dienes, E.; Kosteas, D. 2006. Aluminum structures - a sustainable future?, Structural Engineering International 16(4): 339-344.

http://dx.doi.org/10.2749/101686606778995146

Rajagopalan, N.; Bilec, M. M.; Landis, A. E. 2009. Comparative life cycle assessment of insulating concrete forms with traditional residential wall sections, in IEEE International Symposium on Sustainable Systems and Technology (ISSST '09), 18-20 May, 2009, 1-5.

Sarkisian, M.; Boswell, C. K.; Mathias, N.; Long, E. 2010. Jinao Tower - the design integration of structural efficiency, architectural expression and high performance exterior wall systems, in Proc. of the Munich Tall Building Conference 2010, Munich, Germany, 11 p.

Sarma, K. C.; Adeli, H. 2002. Life-cycle cost optimization of steel structures, International Journal for Numerical Methods in Engineering 55(12): 1451-1462. http://dx.doi.org/10.1002/nme.549

Schlaich, J.; Bergermann, R.; Schiel, W.; Weinrebe, G. 2004. Sustainable electricity generation with solar updraft towers, Structural Engineering International 14(3): 225-229. http://dx.doi.org/10.2749/101686604777963883

Sedano, J.; Chira, C.; Villar, J. R.; Ambel, E. 2013. An intelligent route management system for electric vehicle charging, Integrated Computer-Aided Engineering 20(4): 321333.

Shi, Q.; Xie, X. 2009. A fuzzy-QFD approach to the assessment of green construction alternatives based on value engineering, in International Conference on Management and Service Science (MASS'09), 20-22 September, 2009, Wuhan, China, 1-6.

Steel Recycling Institute. 2013. Steel recycling rates release [online], [cited 10 October 2013]. Available from Internet: http://www.recycle-steel.org/pdfs/SteelRecyclingRates Release.pdf 
Tamboli, A.; Joseph, L.; Vadnere, U.; Xu, X. 2008. Tall buildings: sustainable design opportunities, in Proc. of the CTBUH $8^{\text {th }}$ World Congress, 3-5 March, 2008, Dubai, 120-126.

Tang, D.; Kim, J. 2004. Simulation support for sustainable design of buildings, in Proc. of CTBUH Conference, 1013 October, 2004, Seoul, Korea, 208-213.

Turner, C.; Frankel, M. 2008. Energy performance of LEED for new construction buildings: final report. Washington DC 20056, 4 March, 2008. U.S. Green Building Council (USGBC) [online], [cited 10 October 2013]. Available from Internet: http://www.newbuildings.org/downloads/ Energy_Performance_of_LEED-NC_Buildings-Final_34-08b.pdf
USGBC. 2013. Leadership in Energy and Environmental Design (LEED) rating system [online], [cited 10 October 2013]. Available from Internet: http://www.usgbc.org/ DisplayPage.aspx?CategoryID $=19$

Webster, M. D. 2004. Relevance of structural engineers to sustainable design of buildings, Structural Engineering International 14(3): 181-185. http://dx.doi.org/10.2749/101686604777963874

Wood, A. 2008. Green or grey? The aesthetics of tall building sustainability, in Proc. of the CTBUH $8^{\text {th }}$ World Congress, 3-5 March, 2008, Dubai, 194-202.

Yan, L.; Ma, Z. M. 2012. Comparison of entity with fuzzy data types in fuzzy object-oriented databases, Integrated Computer-Aided Engineering 19(2): 199-212.

Nengmou WANG. He is a graduate student at the Ohio State University. His areas of research interests include building design, sustainability, and vibration control. He has published several papers in Journal of the Franklin Institute and Computer Applications in Engineering Education.

Hojjat ADELI. He is a Professor of Civil, Environmental, and Geodetic Engineering at the Ohio State University. He has authored/co-authored over 270 journal articles in various fields of computer science, engineering, mathematics, and medicine since 1976 when he received his PhD from Stanford University at the age of 26. He has authored/co-authored 15 books. In 1995, he wrote Machine Learning - Neural Networks, Genetic Algorithms, and Fuzzy Sets (published by John Wiley and Sons), the first authored book that covers and integrates the three main areas of soft computing. He also holds a United States patent for his neural dynamic computational model. He is the quadruple winner of The Ohio State University Lumley Outstanding Research Award. In 1998 he received the Ohio State University's highest research honor, the Distinguished Scholar Award "in recognition of extraordinary accomplishment in research and scholarship". In 2005, he was elected Distinguished Member, American Society of Civil Engineers. In 2007, he received the Ohio State University College of Engineering Peter L. and Clara M. Scott Award for Excellence in Engineering Education as well as the Charles E. MacQuigg Outstanding Teaching Award. In 2008, he was elected a Fellow of the American Association for the Advancement of Science (AAAS). He was elected a Fellow of IEEE in 2012. He is the Editor-in-Chief of the international research journal Computer-Aided Civil and Infrastructure Engineering which he founded in 1986. 